\title{
Profit in the Food Desert: Walmart Stakes its Claim
}

\author{
Ivy $\operatorname{Ken}^{1}$
}

Efforts to ensure that people in all neighborhoods have access to healthy, affordable food are essential in the movement for food justice. An organization called the Partnership for a Healthier America has taken on food access as one of its five core areas, and because this organization has the backing of high-profile state representatives and considerable resources, its efforts matter. The Partnership's biggest accomplishments to date involve negotiating "meaningful commitments" from private-sector actors, including the biggest food retailer in the United States, Walmart. In this paper I examine the terms of Walmart's pledge to the Partnership for a Healthier America, and question whether the commitment from this massive corporation is likely to contribute to or obstruct actual food justice. I argue that the relationships this non-profit organization cultivates between the state and the private-sector insulate an entity such as Walmart from regulatory scrutiny, and generate positive publicity and good will for a company that may be doing little more than expanding its market. [Article copies available for a fee from The Transformative Studies Institute. E-mail address: journal@transformativestudies.org http://www.transformativestudies.org (C2014 by The Transformative Studies Institute. All rights reserved.]

KEYWORDS: Food Deserts, Obesity, Neoliberalism, Walmartization, Glocalisation, Governmentality, Consumption, Public-Private Partnerships.

\footnotetext{
${ }^{1}$ Ivy Ken, Ph.D., is Associate Professor of Sociology at George Washington University, where she studies inequality and injustice with a feminist, anti-racist sensibility. Address correspondence to: Ivy Ken, George Washington University, Department of Sociology, Phillips Hall 409, 80122 Street NW, Washington DC 20052; e-mail: ivyken@,gwu.edu. Acknowledgments: I am grateful to Attiya Ahmad, Elisabeth Anker, Jennifer Nash, and Samantha Pinto for writing camaraderie and critique, to Matthew Frizzell for research assistance, and to Steven Tuch and Peg Barratt for research support.
} 